\title{
Storage of blood and the mean corpuscular volume
}

\author{
A. C. K. LAWRENCE, J. M. BEVINGTON, AND M. YOUNG \\ From the Haematology Department, Northern General Hospital, Sheffield
}

SYNOPSIS The mean corpuscular volume (MCV) of blood after storage for up to 24 days under various temperature conditions in ethylene diamine tetracetic acid, acid citrate dextrose, citrate phosphate dextrose, and Alsever's solution was measured using the Coulter S. Storage of blood overnight at $23^{\circ}$ centigrade increased the $\mathrm{MCV}$, while there was no significant change after similar storage at $4^{\circ} \mathrm{C}$. Storage of blood for 23 days at $4^{\circ} \mathrm{C}$ followed by one day at $23^{\circ} \mathrm{C}$ led to a smaller increase of $\mathrm{MCV}$ than storage of blood at $4^{\circ} \mathrm{C}$ for 24 days. Similar results were found with all anticoagulants tested. The precision of the MCV varied on storage with different anticoagulants.

The effect of storage overnight and for 48 hours on the mean corpuscular volume (MCV) of blood in potassium ethylene diamine tetracetic acid (EDTA) is of importance. Lampasso (1968) found no appreciable change of the haematocrit over 48 hours at $4^{\circ} \mathrm{C}$ or at $23^{\circ} \mathrm{C}$ for 24 hours. Brittin, Brecher, Johnson, and Elashoff (1969), using a Coulter Counter model S (Coulter S), showed that the MCV was increased after storage of blood in EDTA at room temperature overnight compared with storage at $4^{\circ} \mathrm{C}$. The other parameters of the Coulter $\mathrm{S}$ blood count remained unchanged.

The effect of storage on the MCV of blood taken into acid citrate dextrose (ACD), citrate phosphate dextrose (CPD), and Alsever's solution is also important as many control preparations use these anticoagulants. The MCV of fresh blood samples diluted in Alsever's solution measured with the Coulter S was found by Parnell (1972) to be in agreement with those of the same blood in EDTA but the MCV of the blood in Alsever's solution increased by some $10 \%$ over 21 days' storage. Lewis (1972) illustrates an approximate $8 \%$ increase of MCV over 20 days of human blood preserved in Alsever's solution.

The present report is concerned with the stability of measurements of the MCV, made with the Coulter $\mathrm{S}$, of blood samples taken in to EDTA, ACD, CPD, and Alsever's solution. The effect of different temperature conditions of storage on the accuracy and precision of the MCV of these blood samples measured with the Coulter $\mathbf{S}$ is described.

Received for publication 30 December 1974.

\section{Apparatus and Methods}

Two Coulter model $\mathbf{S}$ machines were used. One had been in routine use for about five years, and the other was supplied by courtesy of Coulter Electronics Ltd for a short period and was said to be in new condition. The apparatus was used in accordance with the manufacturer's instructions.

All experiments were carried out when the machines appeared to be functioning satisfactorily in routine use.

Blood stored at room temperature was kept at $23^{\circ} \mathrm{C}$. Blood stored at $4^{\circ} \mathrm{C}$ was kept in a refrigerator and brought out for 30 minutes before use. All blood samples were mixed for ten minutes on a roller type mixer before testing. Each test series was completed with a single container of Isoton diluent when the temperature of the diluent and the ambient temperature were within $2^{\circ} \mathrm{C}$ of $23^{\circ} \mathrm{C}$. The stabilized commercial preparation $4 \mathrm{C}$ (Coulter Electronics Ltd) was removed from the $4^{\circ} \mathrm{C}$ refrigerator and mixed for at least 15 minutes before testing.

Blood was collected in plastic containers obtained from Searle Diagnostic. The following anticoagulants were used: (a) dried dipotassium EDTA $8.75 \mathrm{mg}$; (b) $0.5 \mathrm{ml}$ of a solution containing $17.5 \mathrm{mg}$ (42 mmol/litre) dipotassium EDTA; (c) $0.5 \mathrm{ml}$ of acid citrate dextrose solution (ACD) with dextrose (anhydrous) $3.0 \mathrm{~g} / 120 \mathrm{ml}$ (139 mmol/litre) solution and disodium acid citrate $2.0 \mathrm{~g} / 120 \mathrm{ml}(58 \mathrm{mmol} /$ litre); (d) $0.5 \mathrm{ml}$ of the same ACD solution to which glucose had been added to give a concentration of glucose of $4.5 \mathrm{~g} / \mathrm{dl}(250 \mathrm{mmol} /$ litre) of ACD solution; (e) $0.5 \mathrm{ml}$ of CPD solution, citric acid $0.327 \mathrm{~g} / \mathrm{dl}(1.5 \mathrm{mmol} / \mathrm{litre})$, sodium citrate $2.63 \mathrm{~g} / \mathrm{dl}$ 
(8.9 $\mathrm{mmol} /$ litre), sodium dihydrogen phosphate $0.222 \mathrm{~g} / \mathrm{dl}(1.4 \mathrm{mmol} /$ litre $)$, and dextrose $2.55 \mathrm{~g} / \mathrm{dl}$ (141 mmol/litre); $(f) 0.5 \mathrm{ml}$ of Alsever's solution prepared according to Dacie and Lewis (1970). In each case blood was added to yield a final volume of $5 \mathrm{ml}$.

\section{DRIFT OF MCV MEASUREMENT}

The drift of the MCV measurements throughout the day was assessed in order to determine the limits of the size of a batch which could be measured without recalibration. EDTA blood samples requiring routine blood counts were measured using two Coulter machines throughout the day. Three test series of samples were formed where sufficient blood had been supplied for two tests. The first test series was measured in sequence using Coulter $S$ counter 1 and then immediately afterwards was measured in the same sequence using Coulter $\mathbf{S}$ counter 2. Fifty other routine blood samples were measured using Coulter counter 1 . A second series was then measured in sequence using Coulter counter 2 and then the same series was measured using Coulter counter 1 . One hundred routine blood samples were then measured using Coulter counter 1. This was followed by the third test series using Coulter counter 1 first and Coulter counter 2 second. The differences in sample measurements in the three test series were calculated and are presented in table I as differences between measurements with Coulter counter 1 and Coulter counter 2. The average difference of all three measured red cell parameters varies significantly between each series. The difference between the MCV measured with the two Coulter $\mathrm{S}$ machines, as shown in table $\mathrm{I}$, indicates a small change in the calibration of the machine in the course of measurement of 100 samples between the beginning of test series 1 and 2 . A further significant change was found during the measurement of 150 samples between the beginning of test series 2 and 3. Calibration checks were therefore included in every 50 experimental samples.

\section{Results}

PRECISION OF MCV WITH SAMPLES IN DIFFERENT ANTICOAGULANTS STORED OVERNIGHT AT ROOM TEMPERATURE AND $4^{\circ} \mathrm{C}$

The precision of MCV measurements using fresh 0 blood obtained in dried EDTA and ACD anti- coagulants and stored at room temperature over- 3 night was measured. For comparison measurements of the commercial preparation $4 \mathrm{C}$ were included. $\vec{\theta}$ The experiment was carried out twice. The results ov in table II show that there was a significant increase of variance with blood taken into ACD compared with the variation using $4 \mathrm{C}$, and this was more marked after storage at room temperature. In one of the two experiments the variance of the measurements using EDTA blood stored at room temperature was probably significantly different from the variance of measurements of the MCV of the $4 \mathrm{C}$ preparation.

\begin{tabular}{lllll}
\hline Series & $\begin{array}{l}\text { Number } \\
\text { of Samples }\end{array}$ & $\begin{array}{c}\text { Mean Difference }(\text { Coulter Result } \\
1-\text { Coulter Result } 2)(f t)\end{array}$ & SD of Difference & Probability of Occurrence \\
\hline 1 & 27 & -1.52 & 1.42 & Series 1 and 2 compared $t=5.8$ P $<0.001$ \\
2 & 24 & -0.17 & 1.17 & Series 2 and 3 compared $t=12.2 \mathrm{P}<0.001$ \\
3 & 28 & -4.04 & 1.32 & .
\end{tabular}

Table I Differences in measurement of MCV in three series of blood samples with two Coulter model $S$ counters

\begin{tabular}{|c|c|c|c|c|c|c|}
\hline Sample & Anticoagulant & $\begin{array}{l}\text { Storage } \\
\left({ }^{\circ} \mathrm{C}\right)\end{array}$ & $\begin{array}{l}\text { Number of } \\
\text { Replicates }\end{array}$ & Variance & $\begin{array}{l}\text { F Ratio compared } \\
\text { with } 4 C\end{array}$ & $\begin{array}{l}\text { Probability of } \\
\text { Occurrence }\end{array}$ \\
\hline 1 & $\begin{array}{l}\text { EDTA } \\
\text { EDTA } \\
\text { ACD } \\
\text { Coulter } 4 C \text { preparation }\end{array}$ & $\begin{array}{r}22 \\
4 \\
4 \\
4\end{array}$ & $\begin{array}{l}20 \\
18 \\
19 \\
20\end{array}$ & $\begin{array}{l}0.48 \\
0 \cdot 30 \\
0.69 \\
0 \cdot 17\end{array}$ & $\begin{array}{l}2 \cdot 8 \\
1 \cdot 0 \\
4 \cdot 1 \\
-\end{array}$ & $\begin{array}{l}<0.05 \\
\text { Not significant } \\
<0.005 \\
-\end{array}$ \\
\hline 2 & $\begin{array}{l}\text { EDTA } \\
\text { EDTA } \\
\text { ACD } \\
\text { ACD } \\
\text { Coulter } 4 C \text { preparation }\end{array}$ & $\begin{array}{r}22 \\
4 \\
22 \\
4 \\
4\end{array}$ & $\begin{array}{l}15 \\
15 \\
15 \\
15 \\
15\end{array}$ & $\begin{array}{l}0 \cdot 49 \\
0 \cdot 32 \\
1.42 \\
0 \cdot 67 \\
0 \cdot 26\end{array}$ & $\begin{array}{l}1 \cdot 926 \\
1 \cdot 2 \\
5 \cdot 48 \\
2 \cdot 59\end{array}$ & $\begin{array}{l}\text { Not significant } \\
\text { Not significant } \\
<0.005 \\
<0.005\end{array}$ \\
\hline
\end{tabular}

Table II Precision of MCV of blood samples taken into ACD stored at $4^{\circ} C, E D T A$ stored at room temperature overnight, and EDTA stored at $4^{\circ} \mathrm{C}$ overnight, compared with a commercially available blood preparation: similar experiments with different samples on separate days 


\section{ACCURACY OF MEASUREMENTS OF MCV}

AFTER STORAGE OF EDTA AND ACD BLOOD AND EFFECT OF TEMPERATURE FOR THE PERIOD IMMEDIATELY BEFORE THE TEST Blood was taken in duplicate from each of four healthy volunteers into dried EDTA, EDTA solution, and an ACD solution as described in the method section. These samples were all kept at $4^{\circ} \mathrm{C}$. Twenty-three days later a similar series of duplicate samples was obtained from the same inaividuals. One of each of the original duplicates together with one of the duplicates taken 23 days later were brought to room temperature $\left(23^{\circ} \mathrm{C}\right)$ and kept overnight. The other sample of the original series and the other sample of the series taken 23 days later were kept at $4^{\circ} \mathrm{C}$. Finally, 24 days after the original samples were taken a single sample in each of the anticoagulants was obtained. All the samples were now assembled and mixed for 15 minutes and tested. All the samples from the first individual were tested before proceeding to the second, third, and fourth individual's samples. Calibration checks were inserted as described in the method section.

Each sample yielded four measurements. The mean of these measurements was calculated and presented as a difference from the result obtained with fresh blood in the same anticoagulant for that individual. Table III shows that the measured MCV of blood stored for 24 days is higher than that of fresh blood, and the effect is greater using EDTA than ACD as anticoagulant. This effect was not due to dilution of the red cells as there was no difference in the MCV when the same amount of EDTA was dried or dissolved in $0.5 \mathrm{ml}$ of water. In the analysis of differences of the mean MCV between stored and fresh EDTA blood samples, both the mean values from the EDTA samples, irrespective of whether the anticoagulant was liquid or solid, from each of the four subjects was used. The significance of the difference of these eight values for each condition of storage was tested against the corresponding eight values for a different storage condition using Student's $t$ test.

Table III shows there is no significant change of the mean MCV of the EDTA blood samples stored overnight at $4^{\circ} \mathrm{C}$ nor any suggestion of an increase of the mean MCV of ACD samples stored in a similar way overnight. The mean increase of $2 \cdot 1$ femtolitres (fi) of the EDTA samples stored overnight at $23^{\circ} \mathrm{C}$ is probably significant, and there appears to be a similar change of blood in ACD stored at the same temperature.

A comparison of the mean differences of the MCV of EDTA samples stored for 23 days in the same way and then stored for a further day either at room temperature or at $4^{\circ} \mathrm{C}$ showed that removal from

\begin{tabular}{|c|c|c|c|}
\hline \multirow[t]{2}{*}{ Subject } & \multicolumn{3}{|c|}{ Difference of $M C V$ using: } \\
\hline & $\begin{array}{l}\text { EDTA } \\
\operatorname{Dried}(f)\end{array}$ & $\begin{array}{l}\text { EDTA } \\
\text { Solution }(f)\end{array}$ & $\begin{array}{l}A C D \\
\text { Solution }(f)\end{array}$ \\
\hline \multicolumn{4}{|c|}{23 days' storage at $4^{\circ} \mathrm{C}$ and one day at $23^{\circ} \mathrm{C}$} \\
\hline $\mathbf{A}$ & $7 \cdot 75$ & $7 \cdot 75$ & $4 \cdot 0$ \\
\hline B & $9 \cdot 0$ & $7 \cdot 25$ & $3 \cdot 5$ \\
\hline C & $9 \cdot 16$ & 7.75 & $3 \cdot 5$ \\
\hline D & $8 \cdot 75$ & $8 \cdot 75$ & $6 \cdot 25$ \\
\hline \multicolumn{4}{|c|}{24 days' storage at $4^{\circ} \mathrm{C}$} \\
\hline $\mathbf{A}$ & 8.75 & $9 \cdot 75$ & 4.5 \\
\hline B & $9 \cdot 5$ & $9 \cdot 5$ & $5 \cdot 25$ \\
\hline $\mathbf{C}$ & $10 \cdot 5$ & $10 \cdot 25$ & $5 \cdot 25$ \\
\hline D & $11 \cdot 25$ & 11.0 & $7 \cdot 5$ \\
\hline \multicolumn{4}{|c|}{1 day's storage at $23^{\circ} \mathrm{C}$} \\
\hline A & $2 \cdot 25$ & 2.75 & 1.25 \\
\hline B & 3 & 3 & 1.5 \\
\hline C & 1.5 & $2 \cdot 0$ & 1.5 \\
\hline D & 0.75 & 1.5 & 2 \\
\hline \multicolumn{4}{|c|}{1 day's storage at $4^{\circ} \mathrm{C}$} \\
\hline A & 0.75 & 0.25 & 0.25 \\
\hline B & -0.5 & $\mathbf{0}$ & $\mathbf{0}$ \\
\hline $\mathbf{C}$ & -0.5 & -0.75 & -0.25 \\
\hline D & -0.25 & -0.5 & $\mathbf{0}$ \\
\hline
\end{tabular}

Table III Difference of MCV after storage for 24 days and one day of blood in ACD and EDTA: mean sample value compared with mean sample value from fresh blood in the same anticoagulants in four individuals

Probability of occurrence of difference of MCV between fresh EDTA samples and (1) EDTA samples stored at $4^{\circ} \mathrm{C}$ overnight.

Mean difference $=-0.2 \mathrm{fl} t=0.94$ Not significant; and (2) EDTA samples stored at $23^{\circ} \mathrm{C}$ overnight.

Mean difference $=2.1 \mathrm{fl} \quad t=2.58 \quad \mathrm{P}<0.05$.

Mean difference between means of MCV of blood stored for 23 days at $4^{\circ} \mathrm{C}$ and one day at $23^{\circ} \mathrm{C}$ and stored for 24 days at $4^{\circ} \mathrm{C}-1.7 \mathrm{fl}$

Mean difference between means of MCV of blood in EDTA stored for one day at $23^{\circ} \mathrm{C}$ and stored for one day at $4^{\circ} \mathrm{C}+2 \cdot 2 \mathrm{fl}$.

the refrigerator for the last storage day reduced the difference between the MCV of the stored samples and the MCV of the fresh samples by an average of $1.7 \mathrm{fl}$. This is in contrast with the storage of samples for one day when removal from the refrigerator increased the difference between the MCV of the stored samples and the MCV of the fresh samples by an average of $2 \cdot 2 \mathrm{fl}$. Further measurements were made using ACD blood all approximately 25 days old. Nine sets of duplicate samples were taken. All were stored at $4^{\circ} \mathrm{C}$, and one of each pair was removed from the $4^{\circ} \mathrm{C}$ refrigerator and allowed to gain room temperature the night before the tests. All samples were thoroughly mixed and measured at $23^{\circ} \mathrm{C}$. The samples stored wholly at $4^{\circ} \mathrm{C}$ showed a higher MCV. The mean difference between the paired measurements of the MCV was $2.7 \mathrm{fl}(t=$ 8.21, P $<0.001$ ).

Eleven pairs of fresh patient samples in EDTA blood were stored overnight, one of the pair at $4^{\circ} \mathrm{C}$ and one at $23^{\circ} \mathrm{C}$. The samples stored at $4^{\circ} \mathrm{C}$ showed a lower MCV. The mean difference was $1.3 \mathrm{fl}$ $(t=4 \cdot 1, \mathrm{P}<0.01)$. 


\begin{tabular}{|c|c|c|c|c|c|}
\hline \multirow[t]{2}{*}{ Storage } & & \multicolumn{4}{|l|}{ Anticoagulant } \\
\hline & & $\begin{array}{l}\text { ACD Solution } \\
M C V(f)\end{array}$ & $\begin{array}{l}\text { ACD Solution } \\
\text { with Added Glucose } \\
M C V(f)\end{array}$ & $\begin{array}{l}\text { CPD Solution } \\
M C V(f)\end{array}$ & $\begin{array}{l}\text { Alsever's Solution } \\
M C V(f)\end{array}$ \\
\hline \multirow[t]{3}{*}{$\begin{array}{l}\text { Mostly at } 4^{\circ} \mathrm{C}, \\
\text { one night at } 21^{\circ} \mathrm{C}\end{array}$} & $\begin{array}{l}22 \text { days at } 4^{\circ} \mathrm{C} \text { and } \\
\text { one day at } 21^{\circ} \mathrm{C}\end{array}$ & 85 & $85 \cdot 5$ & $85 \cdot 5$ & - \\
\hline & $\begin{array}{l}8 \text { days at } 4^{\circ} \mathrm{C} \text { and } \\
\text { one day at } 21^{\circ} \mathrm{C}\end{array}$ & 84 & 84 & 84 & $84 \cdot 5$ \\
\hline & $\begin{array}{l}4 \mathrm{hr} \text { at } 4^{\circ} \mathrm{C} \text { and } \\
20 \mathrm{hr} \text { at } 21^{\circ} \mathrm{C}\end{array}$ & 82 & $82 \cdot 5$ & $83 \cdot 5$ & $81 \cdot 5$ \\
\hline \multirow{3}{*}{$\begin{array}{l}4^{\circ} \mathrm{C} \text { without } \\
\text { interruption }\end{array}$} & 23 days at $4^{\circ} \mathrm{C}$ & 84 & 84 & $84 \cdot 5$ & - \\
\hline & 9 days at $4^{\circ} \mathrm{C}$ & $84 \cdot 5$ & 84 & $84 \cdot 5$ & 86 \\
\hline & $24 \mathrm{hr}$ at $4^{\circ} \mathrm{C}$ & $83 \cdot 5$ & $83 \cdot 5$ & 83 & $82 \cdot 5$ \\
\hline
\end{tabular}

Table IV Difference of MCV after storage for periods up to 22 days under different temperature conditions in $A C D, A C D$ with added glucose, $C P D$, and Alsever's solution

STORAGE OF BLOOD IN ACD, CPD, AND

ALSEVER'S SOLUTION AND EFFECT OF

TEMPERATURE IMMEDIATELY BEFORE THE TEST

The effect of storage of blood taken into ACD solution, ACD solution with added glucose as described in the method section, CPD solution, and Alsever's solution was studied.

Duplicate $4.5 \mathrm{ml}$ samples of blood were taken into $0.5 \mathrm{ml}$ of each anticoagulant from a single healthy volunteer on three occasions. All were tested on the same day in one batch. The first samples were taken 22 days before the testing day, the second samples nine days before the testing day, and the third samples one day before the testing day. All samples were kept at $4^{\circ} \mathrm{C}$ until the night before the test. One of each pair was removed and brought to $21^{\circ} \mathrm{C}$ overnight. At the time of the test all samples were mixed at $21^{\circ} \mathrm{C}$ for at least 15 minutes. The test sequence began with the oldest sample which had been brought out of the refrigerator the night before to the youngest treated in the same way for each anticoagulant in turn. The duplicate samples which had been kept at $4^{\circ} \mathrm{C}$ continued to mix at $21^{\circ} \mathrm{C}$ during the above testing and were then tested in the same sequence. Each sample yielded two measurements and the mean values of the MCV are given in table IV. The results show a change similar to that of blood stored in ACD in the previous experiment, and it appears that blood in CPD and Alsever's solution shows MCV changes similar to those of blood in $A C D$, and that increased tonicity of the anticoagulant solution and the addition of glucose do not affect this change on storage.

\section{Discussion}

The effect of storage in a wide range of anticoagulants including dipotassium EDTA and ACD solu- tion over a period of 24 days is to increase the MCV measured with the Coulter $\mathrm{S}$. The change is less marked with ACD solution than with EDTA. The MCV of fresh blood in both of these anticoagulants is unchanged after storage for one day at $\vec{\varphi}$ $4^{\circ} \mathrm{C}$ but increased if the storage temperature is $23^{\circ} \mathrm{C}$. of Again this swelling is less marked with ACD solution than with EDTA. The temperature during the last 24 hours before testing has different effects on the $\mathrm{MCV}$, depending on the age of the samples. Cells stored for 23 days at $4^{\circ} \mathrm{C}$ when restored to $23^{\circ} \mathrm{C}$ for 24 hours show lower MCV measurements than similar samples taken at the same time from the same individuals and kept at $4^{\circ} \mathrm{C}$ until 20 minutes before testing. The opposite effect is found with fresh cells kept at $23^{\circ} \mathrm{C}$ for one day compared with cells kept at $4^{\circ} \mathrm{C}$. The range of temperature and time following removal from the $4^{\circ} \mathrm{C}$ refrigerator to produce the effects measured of reduction or increase of MCV depending on the age of the blood sample was not explored.

The variance of the measurement of MCV of cells kept in ACD solution overnight at $4^{\circ} \mathrm{C}$ shows a significant increase although this does not occur using EDTA. Storage overnight at $22^{\circ} \mathrm{C}$ in ACD solution causes a more marked increase of variance of the MCV measurement.

The use of red cells taken into a similar ACD solution has been recommended as a stable control material suitable for standardization of the blood counting apparatus and performance checking throughout the day of the haemoglobin concentration and red cell count (Cavill and Jacobs, 1973). These authors state that $20 \mathrm{ml}$ aliquots may be stored at $0-4^{\circ} \mathrm{C}$ for up to 14 days. The recommended procedure includes removing an unopened $20 \mathrm{ml}$ aliquot of ACD blood from the $0-4^{\circ} \mathrm{C}$ refrigerator at the beginning of each day and mixing this for 15 minutes before use. It is well known that white cells 
are poorly preserved under these conditions. The present results indicate the limitations of the use of blood in ACD handled in this way for control of the MCV.

Daily standardization of the MCV measured by the Coulter $\mathbf{S}$ using such a preparation may be possible for a few days, but within eight days the MCV would be significantly increased. This would lead to a slow downward drift of the calibration of the MCV. A further disadvantage of ACD blood for standardization is that the precision of the MCV of ACD blood is reduced compared with the MCV of the $4 \mathrm{C}$ control material.

A single sample of ACD blood removed from the $4^{\circ} \mathrm{C}$ refrigerator and used for performance checking throughout a day at average ambient temperatures in the United Kingdom will show a small change in the MCV. The extent and direction of the change depend on the age of the sample; fresh samples will show a small increase, but samples 23 days old will show a small decrease.

ACD blood dispensed in aliquots of $5 \mathrm{ml}$, stored at $4^{\circ} \mathrm{C}$, followed by mixing for 15 minutes, and used within an hour would be suitable as a continuing performance check of the MCV. Small plastic containers for the control blood could be used which would be similar to the commonly used test sample containers.

The effect of refrigeration on the MCV of samples previously kept at room temperature for a period of one or two days has not been investigated but would be of interest, particularly in relation to the handling of interlaboratory control material.

\section{References}

Brittin, G. M., Brecher, G., Johnson, C. A., and Elashoff, R. M. (1969). Stability of blood in commonly used anticoagulants. Amer. J. clin. Path., 52, 690-694.

Cavill, I. and Jacobs, A. (1973). Quality control in haematology. Ass. clin. Path. Broadsheets, 75.

Dacie, J. V. and Lewis, S. M. (1970). Practical Haematology, 4th ed., p. 536. Churchill, London.

Lampasso, J. A. (1968). Changes in hematologic values induced by storage of EDTA human blood for varying periods of time. Amer. J. clin. Path., 49, 443-447.

Lewis, S. M. (1972). Developing a blood-cell standard. In Modern Concepts in Haematology, edited by G. Izak and S. M. Lewis, pp. 217-229. Academic Press, New York and London.

Parnell, D. H. (1972). A quality control system for the Coulter Counter model 'S'. Med. Lab. Technol., 29, 401404. 